OPEN ACCESS

Edited by:

Peter B. Marschik,

University Medical Center

Göttingen, Germany

Reviewed by:

Priya Soni

Cedars Sinai Medical Center,

United States

Livia Rosa-Fernandes,

University of Southern

Denmark, Denmark

${ }^{*}$ Correspondence: Maria Elisabeth Lopes Moreira elisabeth.moreira@iff.fiocruz.br

Specialty section:

This article was submitted to Child and Adolescent Psychiatry,

a section of the journal

Frontiers in Psychiatry

Received: 22 April 2021

Accepted: 30 July 2021

Published: 30 August 2021

Citation:

Amaral YNV, Malacarne J, Brandão $P G$, Brasil $P$ Nielsen-Saines $K$ and Moreira MEL (2021) Time to Evaluate the Clinical Repercussions of Zika Virus Vertical Transmission? A Systematic Review.

Front. Psychiatry 12:699115. doi: 10.3389/fpsyt.2021.699115

\section{Time to Evaluate the Clinical Repercussions of Zika Virus Vertical Transmission? A Systematic Review}

\author{
Yasmin Notarbartolo di Villarosa do Amaral ${ }^{1}$, Jocieli Malacarne ${ }^{1}$, \\ Paloma Glauca Brandão ${ }^{1}$, Patrícia Brasil ${ }^{2}$, Karin Nielsen-Saines ${ }^{3}$ and \\ Maria Elisabeth Lopes Moreira ${ }^{\text {* }}$
}

\begin{abstract}
${ }^{1}$ Department of Pediatrics, Instituto Fernandes Figueira, Rio de Janeiro, Brazil, ${ }^{2}$ Department of Acute Febrile Illnesses, Instituto Nacional de Infectologia, Rio de Janeiro, Brazil, ${ }^{3}$ Department of Pediatrics, University of California, Los Angeles, Los Angeles, CA, United States
\end{abstract}

Background: Vertical transmission of Zika Virus (ZIKV) can be associated with several clinical features in newborn infants. The goal of the present review was to analyze the current state of knowledge regarding clinical repercussions following perinatal exposure to ZIKV in children up to 3 years of age.

Methods: A systematic review of published studies was carried out, without the restriction of language or date of publication, identified in the databases PubMed, Virtual Health Library (BVS), Scopus, and Web of Science and the catalog for CAPES theses and dissertations. According to the proposed flowchart, the bibliographic search resulted in 1,563 papers. Of these, according to the eligibility criteria, 70 were selected for systematic review; all were published between 2016 and 2021.

Results: Regarding clinical findings, 19 papers evaluated clinical imaging alterations, 21 ophthalmic manifestations, and 39 evaluated the central nervous system; of these, 15 analyzed neuro-psychomotor development. The remainder evaluated audiological ( $n=14)$, nutritional $(n=14)$, orthopedic $(n=7)$, cardiorespiratory $(n=5)$, genitourinary $(n=3)$ or endocrinological $(n=1)$ manifestations.

Conclusion: It is critical for studies to continue monitoring children with antenatal ZIKV exposure as they grow, given the unknown long-term repercussions of ZIKV and the recognized postnatal complications of this infection during pregnancy. Broader descriptions of observed clinical findings are also important in order to characterize the entire spectrum of disease in children.

\section{Systematic Review Registration: PROSPERO REGISTER: CRD42020205947.}

Keywords: zika virus, systematic review, neurological repercussion, clinical repercussion, neurodevelopment

\section{BACKGROUND}

Zika virus (ZIKV) was first reported in East Africa in the 1950 s. In 2007, global attention emerged following an outbreak in Micronesia, and in the following decade, on the island of Yap, in the French Polynesia. The virus spread widely in other Pacific islands over the years, before emerging as a widespread epidemic throughout Latin America $(1,2)$. In 2015, with the arrival of ZIKV in Brazil, the first studies reported descriptions of women with fever and rash during pregnancy and a possible relationship with congenital microcephaly (3-5). The hypothetical relationship between 
ZIKV infection in pregnancy and subsequent abnormal newborn findings arose after a very large increase in microcephaly cases was observed in Brazil a few months after ZIKV circulation was identified in the country. Due to its catastrophic repercussions to newbor infants, the World Health Organization (WHO) declared Zika virus a Public Health Emergency in 2016. Gradually over 2017, ZIKV cases declined consistently across the world, although certain tropical areas of the globe became endemic for ZIKV infection, including Central and South America, the Caribbean, and southern Asia. Outbreaks were reported in 2018 in India and Angola, and in France, a locally acquired infection was reported in 2019. One of the driving forces behind the rapid ZIKV epidemic spread was global warming and population mobility which greatly contributed to an increase in the environmental span of Aedes sp. mosquitoes. The possibility of new outbreaks lingers, particularly since arboviral outbreaks are notoriously cyclical. In addition, ZIKV, unlike other arboviral infections, can be transmitted by sexual contact. Therefore, pregnant women may be infected by partners who traveled to endemic areas. Therefore, travel histories should include not only the pregnant patient but their partners as well. Since the virus can persist for extended periods of time in semen, pregnant women could be at risk for infection weeks to months following partner travel to endemic areas.

The fact that ZIKV has a very similar genomic structure to dengue viruses $1-4$, has important diagnostic implications. Arboviral flaviviruses in the same family as ZIKV include yellow fever, Japanese encephalitis, and West Nile viruses. Hepatitis $\mathrm{C}$ virus, another flavivirus, also shares some genomic similarities with ZIKV, which carries potential antiviral treatment implications. Over time ZIKV evolved from the African lineage to the Asian lineage (there is $90 \%$ homology between strains), and potentially acquired higher teratogenic potential during the process. The Asian strain of ZIKV was responsible for the recent pandemic.

Although ZIKV infection is generally asymptomatic, 20\% of patients develop mild symptoms. The clinical features resemble that of rubella virus infection. If symptoms occur, they are present 7-10 days following exposure. Most prominent findings are a maculopapular pruritic rash, arthralgia and conjunctival erythema. Fever is rare and, if present, low grade. Rash, pruritus, conjunctival hyperemia, no fever, no petechiae and no anorexia are used as a ZIKV case definition in endemic settings, where dengue and chikungunya are also prevalent. ZIKV infection is typically self-limited with resolution of symptoms within 1 week. Most patients recover without complications, including pregnant women.The absence of clinical symptoms of ZIKV during pregnancy, however, does not indicate no risk of clinical repercussions to infants. Women with asymptomatic disease can deliver infants with microcephaly. Virus load during maternal

\footnotetext{
Abbreviations: ASD, autism spectrum disorder; BVS, biblioteca virtual em saude - (virtual health library); CAPES, coordenação de aperfeiçoamento de pessoal de nível superior (thesis repository); CNS- central nervous system; CZS, congenital zika syndrome; PRISMA, preferred reporting items for systematic reviews; SD, standard deviation; TORCH, toxoplasmosis, rubella, cytomegalovirus, herpes simplex; ZIKV, zika virus.
}

infection, disease severity and frequency of symptoms, as well as prior dengue immunity have not been predictive of infant outcomes at birth.

The Centers for Disease Control and Prevention (CDC) coined the term Congenital Zika Syndrome (CZS) which refers to infants most severely affected by antenatal ZIKV exposure. Nevertheless, many studies demonstrated a spectrum of clinical manifestations in children ranging from absent findings to severe microcephaly. CZS is defined as a constellation of findings at birth including: (1) severe microcephaly ( $>3$ $\mathrm{SD}$ below the mean for gestational age and gender); (2) brain abnormalities (subcortical calcifications, ventriculomegaly, cortical thinning, gyral pattern anomalies, hypoplasia of the cerebellum, or corpus callosum anomalies); (3) ocular findings; (4) congenital contractures, also known as arthrogryposis; and (5) neurologic impairment. Microcephaly rates range from 3 to $7 \%$ in prospective studies. Most common abnormalities include cerebral calcifications, cortical developmental malformations (lissencephaly, pachygyria, agyria), ventriculomegaly due to brain atrophy, posterior fossa alterations including brainstem or cerebellar hypoplasia, corpus callosum abnormalities, enlarged extra-axial cerebrospinal fluid spaces, and enlarged cisterna magna. Ophthalmologic and sensorineural hearing loss have been reported in 7 and $12 \%$ of infants, respectively, followed since the time of maternal infection. They prevail in children with other CNS findings but can also be an isolated finding. Eye manifestations include abnormalities of the retinal pigment epithelium of the macula, optic nerve hypoplasia, chorioretinal atrophy; other abnormalities are colobomas and microphthalmia. Abnormal visual function is identifiable in early infancy among affected children. Eye abnormalities do not tend to progress. Another interesting observation, which highlights some similarities with congenital rubella syndrome is that $10 \%$ of children with in utero ZIKV exposure had congenital heart defects in prospective studies. Longer term outcome studies demonstrated that $15 \%$ of children may have severe neurodevelopmental problems and sensorineural abnormalities by 3 years of age. Conversely, not all children with abnormalities at birth have later neurodevelopmental repercussions. In the same way, infants found to be normal at birth following maternal infection during pregnancy might have abnormal developmental outcomes years later. Studies demonstrated that close to $1 / 3$ of infants with antenatal ZIKV exposure have below average neurodevelopment or abnormal eye or hearing findings, Secondary microcephaly, which is microcephaly occurring after birth, as well as a higher rate of ASD have been noted in children exposed to antenatal ZIKV, underscoring that long term followup is necessary.

ZIKV has been shown to cross the placenta and infect placental macrophages. This disrupts neural progenitor cell evolution, leading to microcephaly in animal models. Maternal infection earlier in pregnancy leads to more severe fetal outcomes. CNS malformations are more common with first and second trimesters infections. Late term fetal demise can occur due to placental vascular involvement with focal necrotic vasculitis and placental failure. In summary, adverse outcomes due to ZIKV infection have been described across all trimesters 
of pregnancy. Miscarriages and fetal growth restriction have also been described. The virus can induce CNS calcifications and bone fusion; craniosynostosis may be present in congenital ZIKV infection.

Congenital ZIKV infection has become widely recognized since its original description. Microcephaly is defined as a head circumference of $<2$ or more standard deviations from the benchmark for gender, age, or gestational age, per the Brazilian Ministry of Health (6). The spectrum of congenital disabilities linked to ZIKV besides microcephaly, such as eye alterations, craniofacial disproportion, and joint and limb deformities, characterize Congenital ZIKV Syndrome (CZS) (7). As previously discussed, clinical alterations and subsequent developmental delays are widely described in babies born without microcephaly, in some cases infants with no stigmata of CZS (812). However, there is very little information about future clinical implications of antenatal ZIKV infection in the long term, and this is the target of several studies.

\section{METHODS}

A systematic review was undertaken to analyze the current state of knowledge regarding repercussions of vertical exposure to ZIKV on child health. The search for pertinent studies was carried out using databases of the Virtual Health Library (BVS), MEDLINE via PubMed, Web of Science, and Scopus via Capes journals portal, CAPES thesis, and dissertation catalogs.

This comprehensive review was undertaken to address the following question: "What is the impact of vertical exposure to ZIKV on clinical, nutritional, and neurodevelopmental aspects in children up to 3 years of age?" This question was formulated per the PICO acronym. The description of this systematic review was based on the Preferred Reporting Items for Systematic Reviews (PRISMA) guidelines (13). Thus, the following steps were developed: identification of the research question, literature search, data evaluation, analysis of results, and presentation of the review (Figure 1).

The following descriptors were used for the search strategy: "Zika Virus," "Zika Virus Infection" as search terms, along with "Zika Virus Infection/complications" or the specific clinical outcome designations: "neurogenic bladder," "urinary bladder," "Nutritional status," "nutrition," "Anthropometry," "Hearing," "Orthopedics," "arthrogryposis," "vision," "Neurologic disease," "Neurologic Manifestations," "Gastrointestinal Diseases," "Cardiovascular disease," "Cardiovascular Abnormalities," "neurodevelopment." Boolean operators AND, OR, and NOT were used to relate the blocks to each other, to add at least one word from each block. This systematic review was registered and approved by the PROSPERO systematic review protocol registry database under registration number CRD42020205947.

Two independent researchers carried out the search process, which ended in January 2021, with no limits for the period of publication or language restrictions. The bibliographic search resulted in 1,563 papers. Of these, 159 were selected for full-text reading because they evaluated clinical manifestations in cohorts of children with antenatal ZIKV exposure. After extensive selection, 89 papers were excluded because they addressed topics that were not relevant to the present work, leaving 70 studies eligible for this paper, as seen in Figure 1. Eligibility criteria for manuscript selection included full text studies that reported clinical findings/outcomes in cohorts of children with documented antenatal ZIKV exposure. As such, incomplete manuscripts/abstracts, review papers, studies in fetuses, animal studies, in vitro studies, studies in adults only, and qualitative studies were excluded. In addition, manuscripts referenced in papers selected for this study were also investigated, however no further papers were identified. The selected publications were compared in regards to the following parameters: year of publication, study location, sample size, mean age of participants, design type, eligibility criteria, exposure period, presence of a control group, symptoms, controlled confounders in the analysis, study limitations, and main results.

\section{RESULTS}

Seventy papers published from 2016 to 2021 were selected following the search. Of these, most were conducted in Brazil $(n=58)$, followed by Colombia $(n=4)$, the U.S. $(n=3)$, Spain $(n=2)$, French Guiana $(n=1)$, Mexico $(n=1)$, and the French Polynesia $(n=1)$ (Figure 2). The sample size ranged from 1 to 5,673 participants. The population studied ranged in age from 0 days to 48 months, with 9 studies not reporting the participant age range (Table $\mathbf{1}$ ).

Most studies were $(n=37)$ descriptive in design, such as case series or case reports, followed by cross-sectional studies ( $n=17)$, cohort studies $(n=14)$, and case-control studies $(n=2)$. Information on study limitations was described in 40 studies; the most prevalent limitation was the limited sample size, lack of a control group, type or lack of laboratory confirmation for ZIKV, loss to follow-up, and use of secondary data for analysis. Details on duration of follow-up, sample size and study design are shown in Figure 3.

Concerning clinical findings, 19 papers evaluated clinical imaging alterations, 21 ophthalmic manifestations, 39 the central nervous system, including 15 which evaluated neuropsychomotor development. Additional studies included audiological $(n=14)$, nutritional $(n=14)$, orthopedic $(n=7)$, cardiorespiratory $(n=5)$, genitourinary $(n=3)$ or endocrinological $(n=1)$ manifestations. It is noteworthy that some articles described more than one organ system and multiple clinical findings (Table 2).

The most prevalent clinical imaging abnormalities of the central nervous system included microcephaly, ventriculomegaly, cortical malformations, mega cisterna magna, hydrocephalus, cerebellum or brain stem hypoplasia, and cerebral calcifications, especially at the junction between the cortical and subcortical white matter $(16,18,21,25,34,45,46,48,50,53,56,59-61,75,77)$. One manuscript also reported a decline in head circumference growth (70). Regarding abdominal imaging, there were no characteristic abnormalities identified in ZIKV exposed children that differed from descriptions in the general population. 


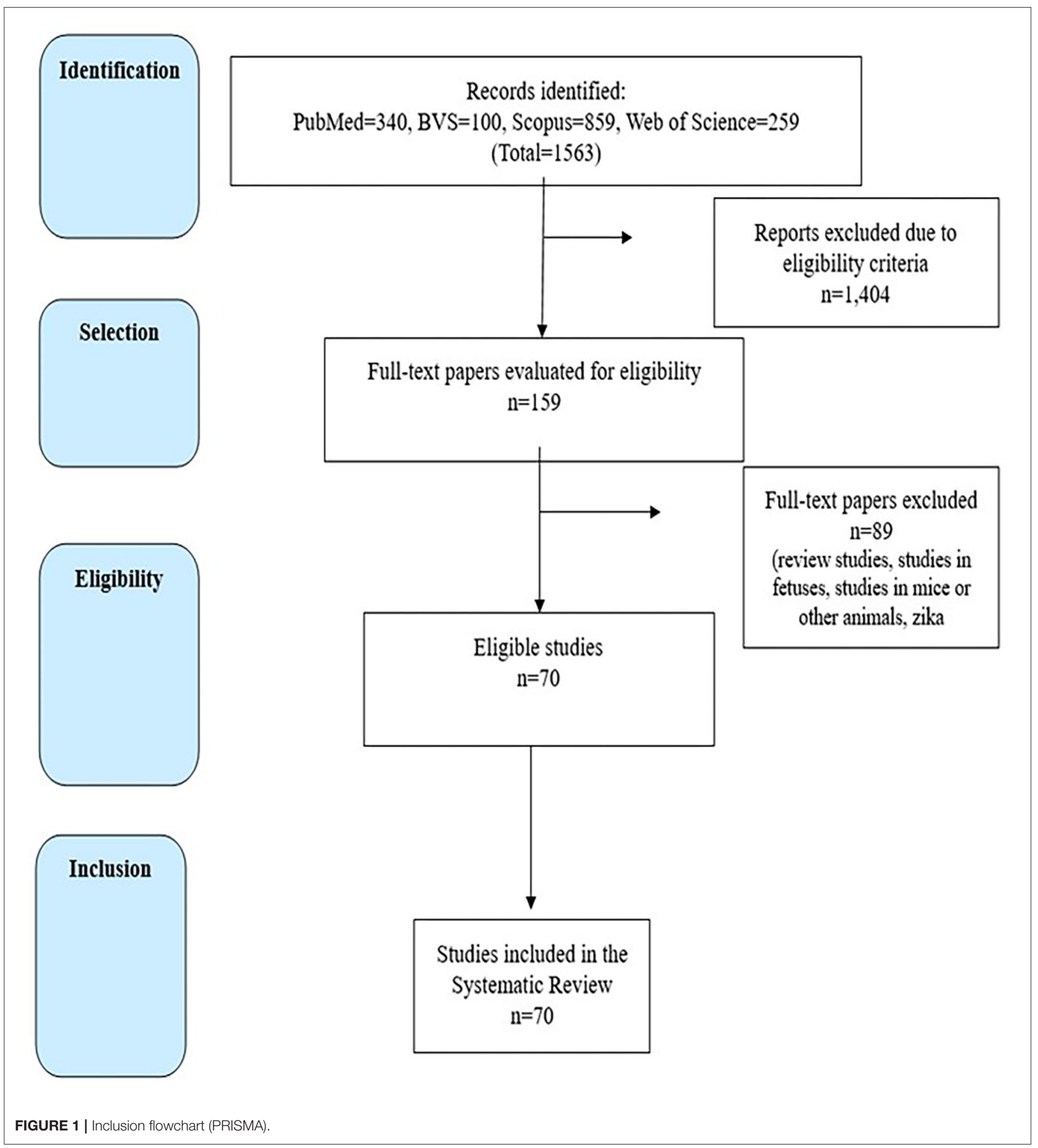

Imaging results were normal in $95.3 \%$ of 106 children who underwent abdominal ultrasound (55). Of five patients with abnormal abdominal ultrasounds, one (16.6\%) had a splenic cyst, one $(16.6 \%)$ had a diaphragmatic eventration, one $(16.6 \%)$ had biliary lithiasis, one (16.6\%) had multi-cystic dysplastic kidney, and two $(33.4 \%)$ had a dilated renal pelvis. The prevalence of these alterations was $1.9 \%$ for renal pelvis dilatation and $0.9 \%$ for other abnormalities (55).

All the papers that evaluated the central nervous system found neurological alterations, and the main ones were seizure, epilepsy, irritability, pyramidal syndrome, sleep disorders, and hyperexcitability $(5,12,18,19,27,31,35,36,42,45,46,48,50,51$, 


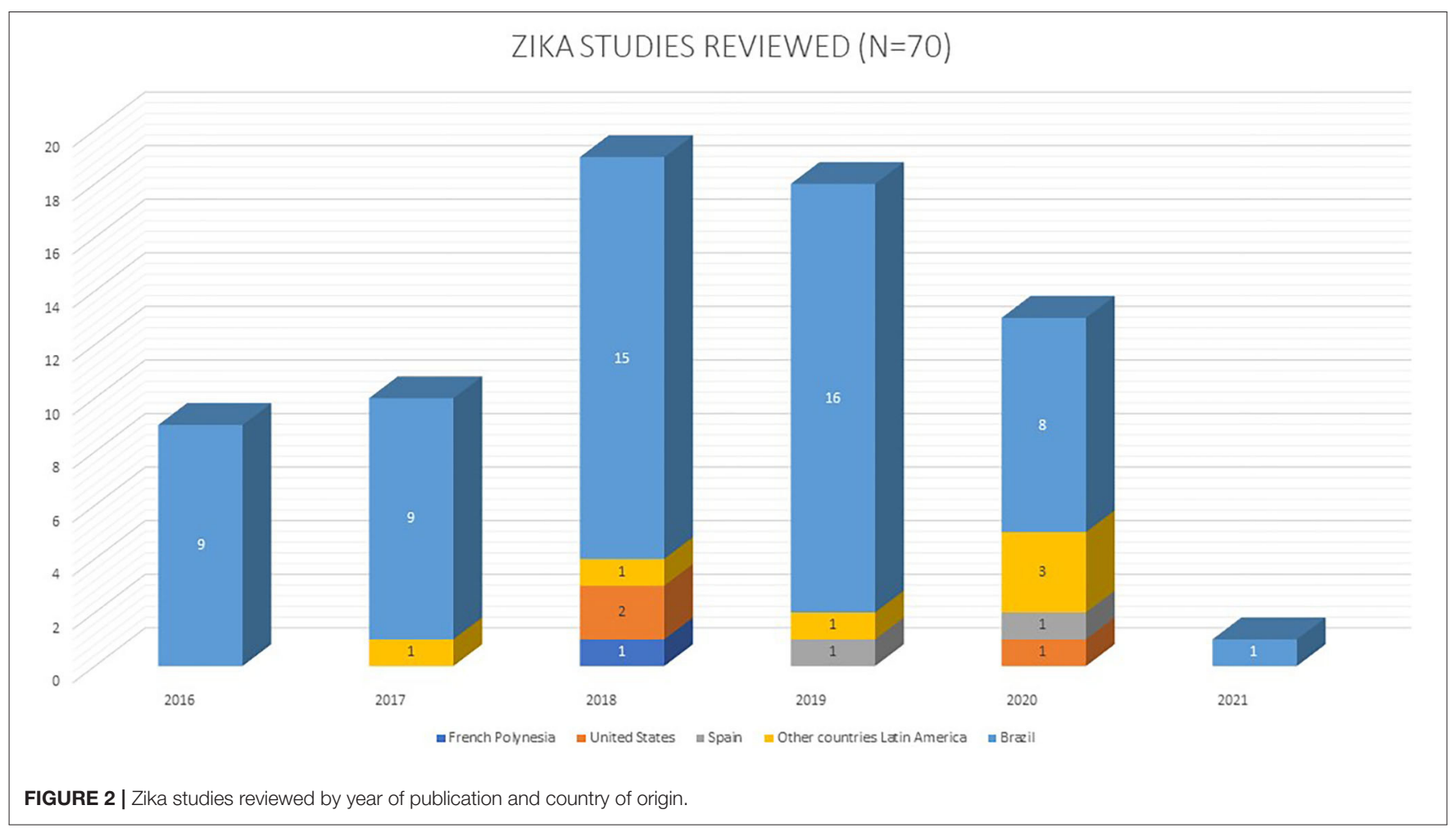

54, 56, 61, 62, 66, 69-71, 74, 77). Regarding neuro-psychomotor development, all 15 papers reported motor, cognitive, or language delay $(10,11,15,17,18,24,32,33,44,47,52,58,61,62,65)$. Noteworthy is that, in one paper, the authors reported autism spectrum disorder in three previously healthy children in the second year of life (11).

All studies that performed ophthalmological evaluations exposed some alteration, such as microphthalmia, fundoscopic alterations, macular atrophy, optic nerve abnormalities, strabismus and visual acuity defects $(12,14,27,36,45,50,51,56,60,61,67,68,73-$ 79). Twelve of 14 papers that evaluated audiological manifestations in children reported hearing disorders $(11,14,27,36,37,39,43,51,56,60,62,64)$ and two did not observe any abnormalities $(30,41)$.

Two papers reported unilateral diaphragmatic paralysis (45, 57 ), and another two found echocardiographic abnormalities $(49,61)$. These abnormalities were characterized by dilatation of the right atrium and the right ventricle, demonstrating an overload of the right heart chambers. In a study of children with Zika-related microcephaly, adenoid hypertrophy and symptoms of respiratory obstruction were reported (40).

Regarding genitourinary characteristics, studies reported neurogenic bladder and cryptorchidism $(22,23,72)$. The most common orthopedic alteration was arthrogryposis (12, 16, 21, 36, 42, 46, 57). All papers that evaluated gastrointestinal manifestations reported dysphagia $(38,46,48,61)$. Regarding the nutritional status of children exposed to antenatal ZIKV, nine papers found anthropometric alterations such as low birth weight and growth retardation $(14,20,21,28,29,33,48,50,63,66)$ and one study observed endocrine dysfunctions in children with Zika-related microcephaly (75).

\section{DISCUSSION}

In this section we discuss the main results of manuscripts selected for this systematic review to assess the main potential clinical alterations described in antenatally ZIKV-exposed children to date.

\section{Neurologic, Neuroimaging and Neurodevelopmental Findings}

Concerning clinical imaging alterations, (16, 34, 53, 59), severe brain damage was reported in CNS imaging studies in most children with antenatal exposure to ZIKV. The most common features identified were brain calcifications at the junction between cortical and subcortical white matter; these were associated with malformations of cortical development, usually with a simplified gyrus pattern and a predominance of pachygyria or polymicrogyria in the frontal lobes. Studies also identified an increased/dilated cisterna magna, corpus callosum abnormalities (which could be either hypoplasia or hypogenesis), ventriculomegaly, delayed myelination, and hypoplasia of the brain stem and/or cerebellum.

Petribu et al. (53) observed an interesting finding in that brain calcifications in children with confirmed or presumed CZS tended to decrease over time. This implies that brain calcifications should not be considered essential for diagnosis of $\mathrm{CZS}$ in children who present late to medical attention. Decrease 
TABLE 1 | Year of publication, origin, sample size and age of participants of selected studies, 2016-2021.

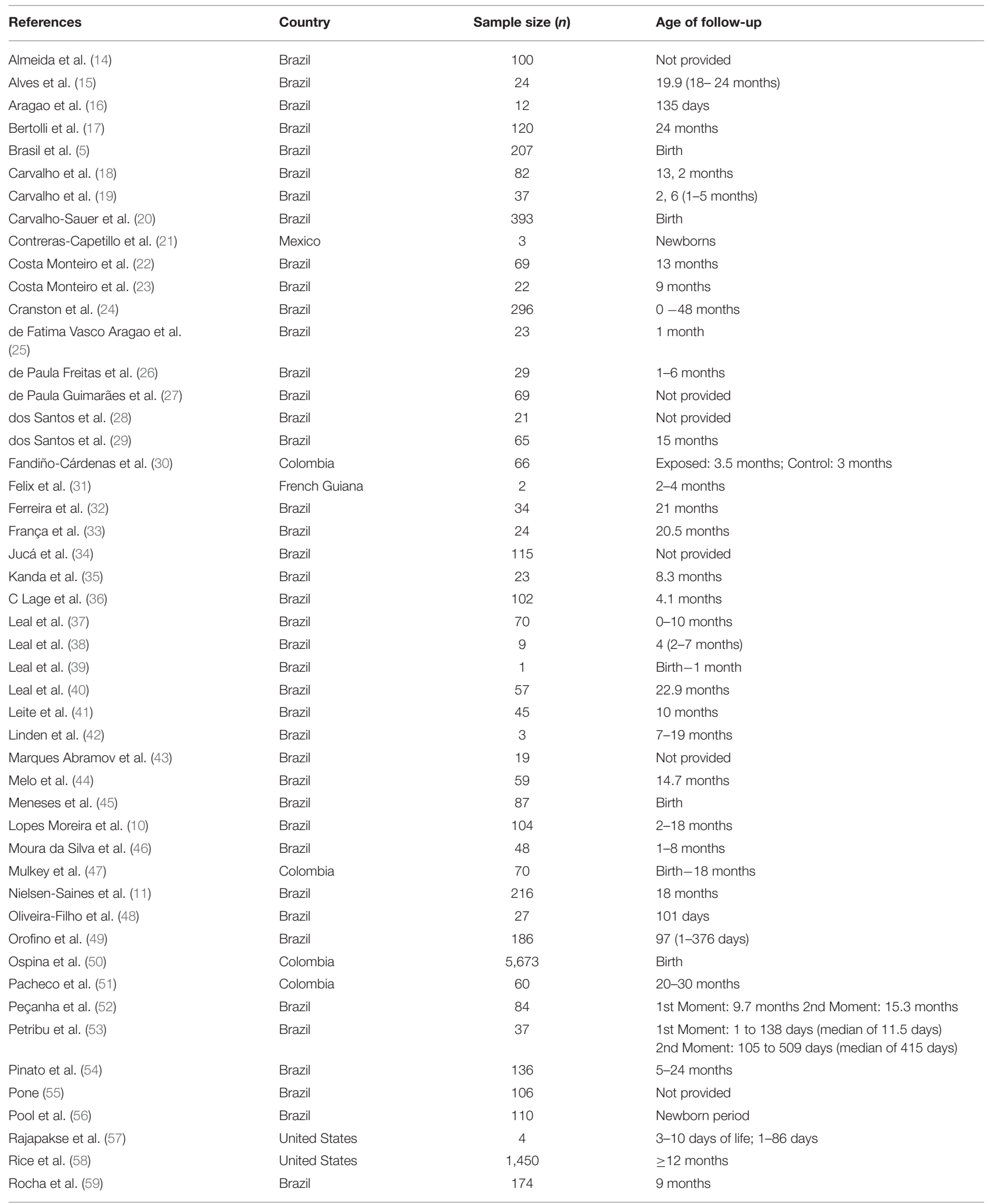


TABLE 1 | Continued

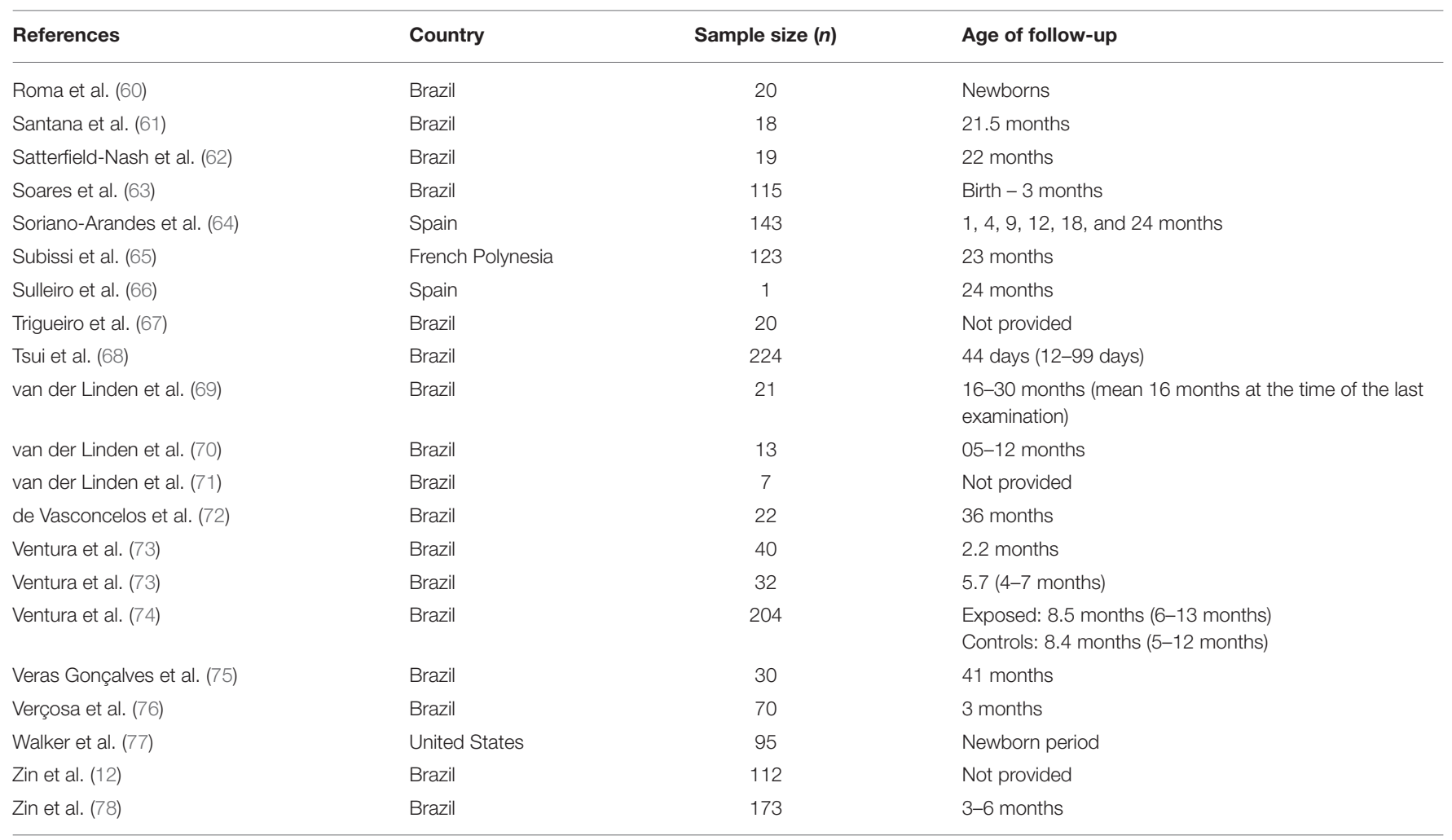

in brain calcifications over time, however, was not associated with clinical improvement.

Santana et al. (61) reported that all children in their cohort had microcephaly, spasticity, and delayed neurological development. Epilepsy was found in 15 of 18 cases (83\%). In a case series, Van Der Linden et al. (70) observed dystonic postures and other frequent and potentially disabling extrapyramidal signs. The study emphasized that early identification of extrapyramidal findings may help recognize neurodevelopmental problems and assist with implementation of rehabilitation, potentially influencing better strategies for rehabilitative interventions.

When analyzing sleep disorders in their cross-sectional study, Pinato et al. (54) showed that the CZS group of children had a shorter total sleep time and night sleep duration than the control group. However, no correlation was found between age and sleep patterns.

In a series of cases that assessed infants exposed to congenital ZIKV who were asymptomatic at birth, neurodevelopmental delay was identified through the use of the Bayley-III scale assessment tool (52). The abnormalities occurred mainly in the language domain during the first two years of life. The Z-score of the head circumference was significantly lower in the group with developmental delay, with the simultaneous presence of neurological abnormalities, which indicates a possible action of ZIKV infection in the developing brain (24).

Nielsen-Saines et al. (11) observed that, among the children evaluated by Bayley-III, 12\% scored below two standard deviations (i.e., a score $<70$; a score of $100 \pm 2$ SD is the variation) in at least one functional domain; $28 \%$ of children scored between
-1 and $-2 \mathrm{SD}$ in any domain (scores $<85-70$ ). Language function was most affected, with $35 \%$ of 146 children being below average. The authors described that neurodevelopmental outcomes were improved in female children, term babies, children with normal eye exames, and whose mothers were infected with ZIKV later in pregnancy. Mulkey et al. (47) found that infants with in utero ZIKV exposure without features of CZS were also at risk for abnormal neurodevelopment in the first 18 months of life.

\section{Eye Findings}

Regarding ophthalmological findings, studies (12, 26, 67, 68, $73,74,76,78-80)$ found an association between congenital infection due to presumed exposure to ZIKV and macular lesions, macular circumscribed chorio-retinal atrophy, focalspotted retinal pigment epithelium, optic nerve pallor, earlyonset strabismus, nystagmus, and low visual acuity. Also, ocular involvement (macular and eye fundus abnormalities) in babies with presumed congenital ZIKV infection was most frequently observed in babies with a smaller head circumference at the time of birth and whose mothers were infected in the first trimester of pregnancy (73).

\section{Hearing Deficits}

Of the papers that assessed audiological function, the main findings were a statistically significant increase in latencies of waves I and III, compared to wave V, absence of otoacoustic emissions, and sensorineural hearing loss $(37,43)$. In most hearing loss cases associated with congenital infections, damage 
A Studies by duration of follow-up ( $n=70$ studies)

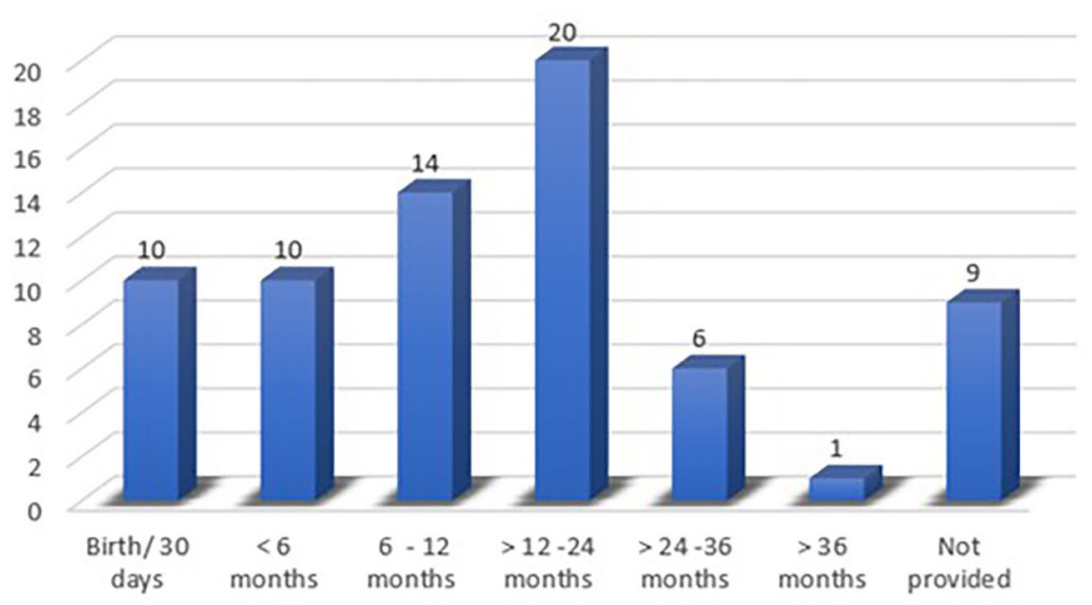

B Studies by number of participants ( $n=70$ studies)

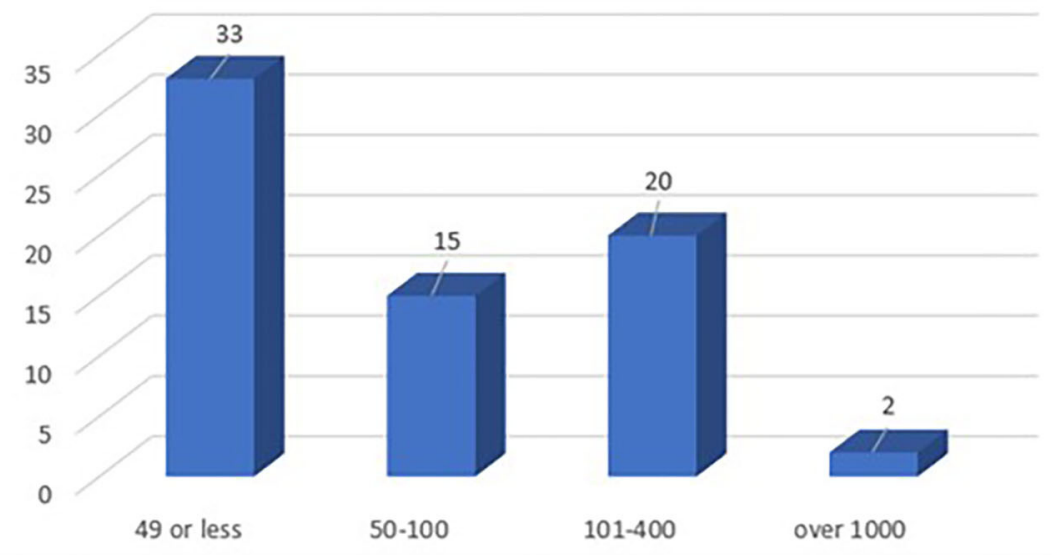

C Distribution of publications by study design

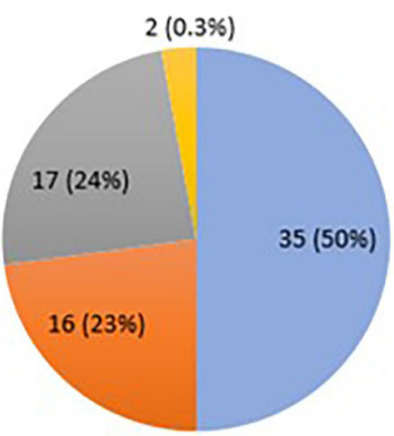

\pm Case series/Case report $\quad$ Cohort $\|$ Cross-sectional $\|$ Case-control 
TABLE 2 | Study design, clinical abnormalities and development screening test, 2016-2021.

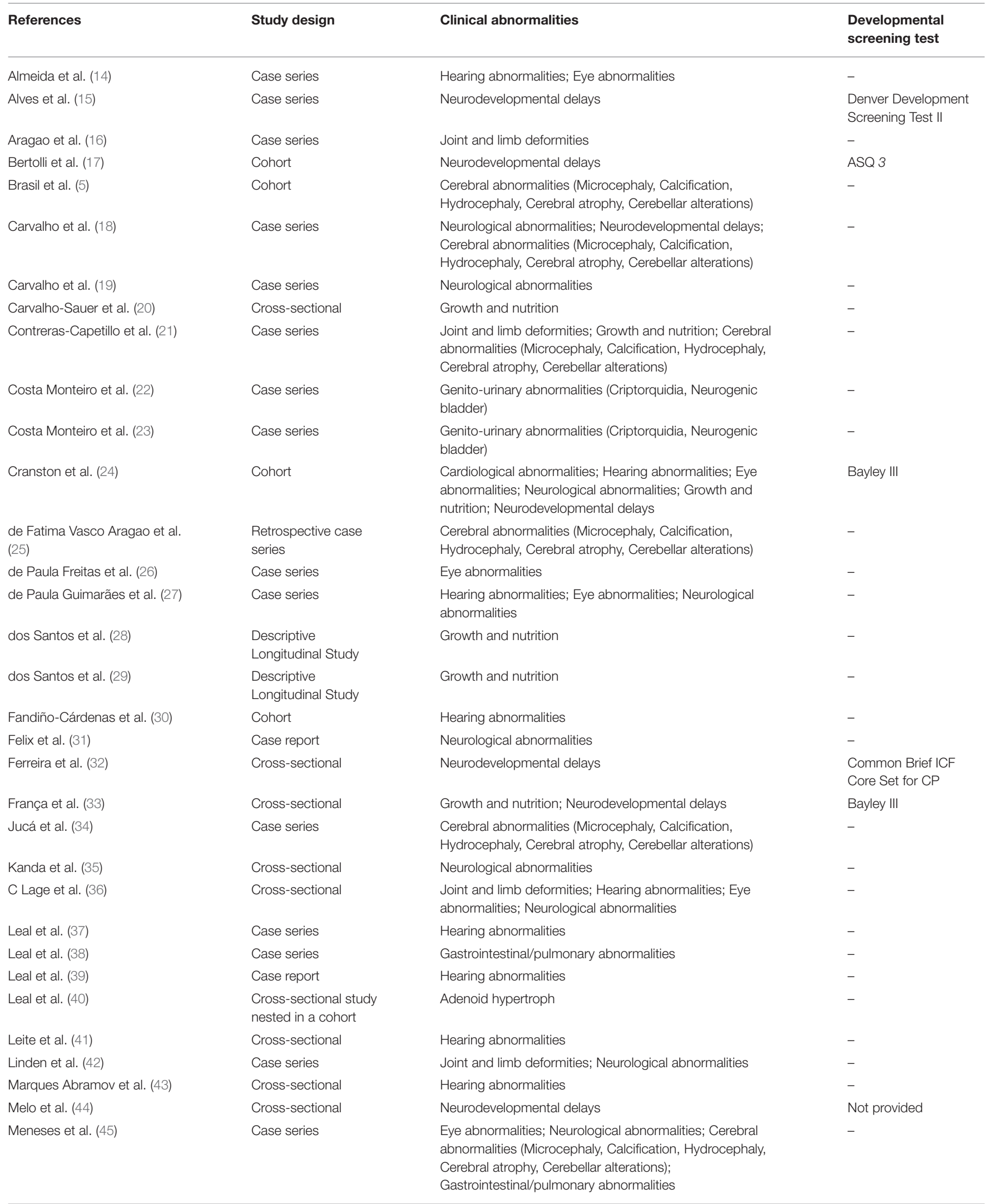


TABLE 2 | Continued

\section{References}

Study design

Cohort

Case series

Mulkey et al. (47)

Nielsen-Saines et al. (11)

Oliveira-Filho et al. (48)

Orofino et al. (49)

Ospina et al. (50)

Pacheco et al. (51)

Peçanha et al. (52)

Petribu et al. (53)

Pinato et al. (54)

Pone (55)

Pool et al. (56)

Rajapakse et al. (57)

Rice et al. (58)

Rocha et al. (59)

Roma et al. (60)

Santana et al. (61)

Satterfield-Nash et al. (62)

Soares et al. (63)

Soriano-Arandes et al. (64)

Subissi et al. (65)

Sulleiro et al. (66)

Trigueiro et al. (67)

Tsui et al. (68)

van der Linden et al. (69)
Cohort

Cohort

Cohort

Cross-sectional

Retrospective cohort

Descriptive study

Case series

Case series

Cross-sectional

Cross-sectional

Retrospective cohort

Case series

Descriptive study

Case-control

Case series

Case series

Case series

Cohort

Cohort

Case-control

Case report

Cross-sectional

Case series

Descriptive study

Clinical abnormalities

Developmental

screening test

Neurodevelopmental delays

Gastrointestinal/pulmonary abnormalities; Joint and limb deformities; Neurological abnormalities; Cerebral abnormalities (Microcephaly, Calcification, Hydrocephaly, Cerebral atrophy, Cerebellar alterations)

Neurodevelopmental delays
Bayley III

$-$

Warner Initial

Developmental Evaluation of Adaptive and Functio-I Skills (WIDEA) and the Alberta Infant Motor Scale (AIMS)

Bayley III

Hearing abnormalities; Neurodevelopmental delays

Gastrointestinal/pulmonary abnormalities; Neurological abnormalities; Growth and nutrition; Cerebral abnormalities (Microcephaly, Calcification, Hydrocephaly, Cerebral atrophy, Cerebellar alterations)

Cardiological abnormalities

Eye abnormalities; Growth and nutrition; Cerebral abnormalities (Microcephaly, Calcification, Hydrocephaly, Cerebral atrophy, Cerebellar alterations)

Hearing abnormalities; Eye abnormalities; Neurological abnormalities

Neurodevelopmental delays

Cerebral abnormalities (Microcephaly, Calcification, Hydrocephaly, Cerebral atrophy, Cerebellar alterations)

Neurological abnormalities

Cerebral abnormalities (Microcephaly, Calcification, Hydrocephaly, Cerebral atrophy, Cerebellar alterations)

Hearing abnormalities; Eye abnormalities; Neurological abnormalities; Cerebral abnormalities (Microcephaly, Calcification, Hydrocephaly, Cerebral atrophy, Cerebellar alterations)

Joint and limb deformities; Gastrointestinal/pulmonary abnormalities

Neurodevelopmental delays

Cerebral abnormalities (Microcephaly, Calcification, Hydrocephaly, Cerebral atrophy, Cerebellar alterations)

Hearing abnormalities; Eye abnormalities; Cerebral abnormalities (Microcephaly, Calcification, Hydrocephaly, Cerebral atrophy, Cerebellar alterations)

Gastrointestinal/pulmonary abnormalities; Cardiological abnormalities; Eye abnormalities; Neurological abnormalities; Neurodevelopmental delays; Cerebral abnormalities (Microcephaly, Calcification, Hydrocephaly, Cerebral atrophy, Cerebellar alterations)

Hearing abnormalities; Neurological abnormalities; Neurodevelopmental delays

Growth and nutrition

Hearing abnormalities; Neurological abnormalities

Neurodevelopmental delays

Neurological abnormalities; Growth and nutrition

Eye abnormalities

Eye abnormalities

Neurological abnormalities
$-$

$-$

$-$

Bayley III

$-$

$-$

Not provided

$-$

Not provided

ASQ 3

$-$

Not provided 
TABLE 2 | Continued

\begin{tabular}{|c|c|c|c|}
\hline References & Study design & Clinical abnormalities & $\begin{array}{l}\text { Developmental } \\
\text { screening test }\end{array}$ \\
\hline van der Linden et al. (70) & Case series & $\begin{array}{l}\text { Neurological abnormalities; Cerebral abnormalities } \\
\text { (Microcephaly, Calcification, Hydrocephaly, Cerebral atrophy, } \\
\text { Cerebellar alterations) }\end{array}$ & - \\
\hline van der Linden et al. (71) & Cohort & Neurological abnormalities & - \\
\hline de Vasconcelos et al. (72) & Case series & $\begin{array}{l}\text { Genito-urinary abnormalities (Cryptorchidism/Neurogenic } \\
\text { bladder) }\end{array}$ & - \\
\hline Ventura et al. (73) & Cross-sectional & Eye abnormalities & - \\
\hline Ventura et al. (74) & Cross-sectional & Eye abnormalities; Neurological abnormalities & - \\
\hline Veras Gonçalves et al. (75) & Case series & Eye abnormalities; Endocrine disfunction & - \\
\hline Verçosa et al. (76) & Case series & Eye abnormalities & - \\
\hline Walker et al. (77) & Retrospective cohort & $\begin{array}{l}\text { Eye abnormalities; Neurological abnormalities; Cerebral } \\
\text { abnormalities (Microcephaly, Calcification, Hydrocephaly, } \\
\text { Cerebral atrophy, Cerebellar alterations) }\end{array}$ & - \\
\hline Zin et al. (78) & Cross-sectional & Hearing abnormalities & - \\
\hline
\end{tabular}

to the auditory system is due to cochlear involvement (81). Similar injuries are likely to be responsible for hearing loss in children with congenital ZIKV infection, although histological studies need to confirm this (39).

In a cross-sectional study, when evaluating 45 children with a mean age of 10 months, Leite et al. (41) found no association between exposure to ZIKV during pregnancy and audiological alterations. Similarly, when comparing children exposed and not exposed to ZIKV, Fandiño-Cárdenas et al. (30), in their cohort study of 66 exposed children did not observe hearing loss in the first two years of life.

In conclusion, hearing loss due to congenital ZIKV can be sensorineural, neural, conductive, isolated, or mixed. Therefore, a complete hearing assessment should be performed on all ZIKVinfected patients to rule out auditory neuropathy syndrome and sensorineural hearing loss (82).

\section{Cardiac Findings/Congenital Heart Disease} When analyzing the cardiovascular system of ZIKV-exposed children, Santana et al. (61) found echocardiographic abnormalities suggesting tropism of ZIKV to tissue beyond the central nervous system. Corroborating this finding, Orofino et al. (49) found a higher frequency of cardiac alterations in ZIKV-exposed babies than in the general population. However, none of these defects were severe. Therefore, the authors suggested that recommendations for performance of fetal echocardiograms in women with ZIKV infection during pregnancy and recommendations for postnatal infant echocardiogram should follow general infant population guidelines.

\section{Genito-Urinary Findings}

All studies concerning genitourinary characteristics were performed in Brazil, two in the state of Rio de Janeiro and one in Pernambuco. Costa Monteiro et al. $(22,23)$ found that more than $90 \%$ of children with microcephaly in their series had neurogenic bladder, a health condition known to cause kidney damage when left untreated. On this theme, de Vasconcelos et al. (72) published a case series describing cryptorchidism in 3-year-old children with ZIKV-related microcephaly.

\section{Nutrition, Gastro-Intestinal Findings and Feeding Difficulties}

Regarding the nutritional status of children exposed to ZIKV, nine papers described anthropometric changes such as low birth weight and growth restriction $(20,21,28,29,33,48,50,66)$.

In a cohort study, Soares et al. (63) found differences in arm and arm muscle circumference and fat-free mass in children from 1 to 3 months of age. Weight and length at 3 months of age were lower in ZIKV-exposed infants. Similarly, CarvalhoSauer et al. (20) concluded that low birth weight in children with CZS was 4-fold greater as compared to children without CZS. Furthermore, prematurity and cesarean delivery were associated with low birth weight in exposed children. It should also be noted that most children with CZS were born to mothers of African heritage, single, and with less years of education, suggesting CZS disproportionately affected disenfranchised populations $(28,63)$.

Leal et al. (38) described a delay in the initial pharyngeal phase of swallowing. This combined with significant oral dysfunction, increases the risk of oral aspiration, predominantly with liquid foods. Also, Santana et al. (61) reported that four of 18 patients who had swallowing impairment were fed by gastrostomy.

In addition, Leal et al. (40) in a cross-sectional study nested in a cohort study, found a high prevalence of adenoid hypertrophy in children with Zika-related microcephaly, with consequent upper airway obstruction leading to chronic upper airway obstructive disorder, secretory otitis media and subsequent dysphagia (40). Abdominal imaging studies on the other hand 
showed no characteristic findings that were higher than those observed in the general population (55).

\section{Musculo-Skeletal Findings}

Regarding orthopedic abnormalities, all seven papers described the presence of arthrogryposis in children with congenital zika, often present in both upper and lower extremities. A study by Aragão et al. (16) found that $75 \%$ of children with microcephaly and $100 \%$ of those with arthrogryposis had reduced thickness of the thoracic spinal cord. However, the latter group had evidence of narrowing of the entire spinal cord, with severely reduced spinal cord anterior roots. The authors concluded that it is crucial to consider Zika virus infection in the differential diagnosis of congenital diseases of the spinal cord and anterior nerve root if mother-infant pair have any risk factors for ZIKV antenatal exposure. This is especially relevant in mild cases where microcephaly is absent, and the only clinical manifestation is, for example, abnormal joints. On the other hand, health professionals should pay close attention when monitoring children from an epidemic area with mild or no clinical signs of spinal cord and anterior nerve root lesions, as they may have future problems with neuropsychomotor development.

\section{Endocrinologic Findings}

Regarding the endocrine system, the most prevalent and clinically relevant problems were pubertal dysfunctions, thyroid disease, growth faltering and obesity. These conditions require careful monitoring and highlight the need for endocrine evaluations in children with CZS, particularly those with microcephaly. Early diagnosis and referral to appropriate treatment in this situation may often be necessary (75).

\section{Need for Long Term Follow-Up}

The repercussions of maternal infection during pregnancy on child development have been extensively described in the literature in regards to classic teratogenic pathogens responsible for TORCH syndromes (26). Fetal infection often triggers a systemic inflammatory response which may persist after birth, compounding further damage to the brain. This is one of the prevailing hypotheses on the pathogenesis of brain injury (26). Lesions associated with deep gray matter injury, vascular compromise and neural progenitor cell dysfunction have also been described (83-85).

Saad et al. (86) made the same recommendation in reviewing the most frequent clinical findings in children born to women with confirmed ZIKV infection during pregnancy. They described a broad spectrum of abnormalities resulting from an inflammatory reaction to the virus or a direct effect of the virus itself, causing damage to the CNS and neurological abnormalities which potentially manifest over time.

These published results describing developmental delay and other neuro-sensory deficits which may manifest later in life point to the need for continued monitoring of children with antenatal ZIKV exposure to assess risks of learning and behavioral disorders in the long term (85).

\section{CONCLUSION}

In this systematic review, the most relevant findings were injuries to the infant central nervous system. CZS is a neurotropic disease with several associated abnormalities. Although the majority of published studies were from Brazil, there were no regional differences across the country and also in comparison to other countries in Latin America. Another important finding which the studies underscored is the later delay in development that may subsequently occur in an apparently normal infant at the time of birth. Finally, due to the vulnerability of women and children and the severe repercussions of ZIKV infection in pregnancy, studies should continue to monitor these children as they age. Broader descriptions of clinical findings are also important to further characterize the spectrum of disease in children. Prospective studies evaluating infants and children with antenatal ZIKV exposure may be able to describe the actual prevalence of adverse pregnancy, infant and childhood outcomes in this population. Prompt recognition of clinical abnormalities allows for implementation of early interventions which can improve later neurodevelopmental pathways in children born to mothers with gestational ZIKV infection.

\section{DATA AVAILABILITY STATEMENT}

The original contributions presented in the study are included in the article/supplementary material, further inquiries can be directed to the corresponding author/s.

\section{AUTHOR CONTRIBUTIONS}

YA, JM, and PGB did the manuscript search, reviewed all the literature and drafted the paper, and approved the final text. PB, $\mathrm{KN}-\mathrm{S}$, and MM formulated the research question, performed the analysis and draft of the paper, and approved the final text. All authors contributed to the article and approved the submitted version.

\section{FUNDING}

This work was supported by the Fiocruz PIP/IFF program, CNPq 441098/2016-9 and 305090/2016-0 grants; Faperj E_18/2015TXB; Wellcome Trust \& the United Kingdoms Department for International Development (205377/Z/16/Z) grants; European Unions Horizon 2020 research and innovation programme under ZikaPLAN grant agreement no. 734584, RO1/AI140718 (NIH/NIAID) research grant. The role the funders was to pay for retrieval of manuscripts that were not open access and provide student scholarships (YA, PGB, and JM). 


\section{REFERENCES}

1. Basu R, Tumban E. Zika virus on a spreading spree: what we now know that was unknown in the 1950's. Virol J. (2016) 13:165. doi: 10.1186/s12985-016-0623-2

2. Wong SS-Y, Poon RW-S, Wong SC-Y. Zika virus infection-the next wave after dengue? J Form Med Assoc. (2016) 115:22642. doi: 10.1016/j.jfma.2016.02.002

3. Oliveira Melo AS, Malinger G, Ximenes R, Szejnfeld PO, Alves Sampaio S, Bispo de Filippis AM. Zika virus intrauterine infection causes fetal brain abnormality and microcephaly: tip of the iceberg?: physician alert. Ultrasound Obstet Gynecol. (2016) 47:6-7. doi: 10.1002/uog.15831

4. França GVA, Schuler-Faccini L, Oliveira WK, Henriques CMP, Carmo EH, Pedi VD, et al. Congenital zika virus syndrome in Brazil: a case series of the first 1501 livebirths with complete investigation. Lancet. (2016) 388:8917. doi: 10.1016/S0140-6736(16)30902-3

5. Brasil P, Pereira JP, Moreira ME, Ribeiro Nogueira RM, Damasceno L, Wakimoto $\mathrm{M}$, et al. Zika virus infection in pregnant women in rio de janeiro. N Engl J Med. (2016) 375:2321-34. doi: 10.1056/NEJMoa1602412

6. Brasil, Ministerio da Saúde (MS). Protocolo de Atendimento: Mulheres em Idade Fértil, Gestantes, Puérperas e Bebês Com Microcefalia. (2015). Available online at: https://bvsms.saude.gov.br/bvs/publicacoes/protocolo_resposta_ microcefalia_relacionada_infeccao_virus_zika.pdf (accessed January 25, 2021).

7. Gulland A. Zika virus may be linked to several birth defects, expert warns. BMJ. (2016) 352:i1322. doi: 10.1136/bmj.i1322

8. Carvalho A de JA, Lemos SMA, Goulart LMH de F. Desenvolvimento da linguagem e sua relação com comportamento social, ambientes familiar e escolar: revisão sistemática. CoDAS. (2016) 28:4709. doi: 10.1590/2317-1782/20162015193

9. DeThorne LS. Rethinking environmental influences on child language development. J Commun Dis. (2015) 57:12. doi: 10.1016/j.jcomdis.2015.09.002

10. Lopes Moreira ME, Nielsen-Saines K, Brasil P, Kerin T, Damasceno L, Pone $\mathrm{M}$, et al. Neurodevelopment in infants exposed to zika virus in utero. $\mathrm{N} \mathrm{Engl} \mathrm{J}$ Med. (2018) 379:2377-9. doi: 10.1056/NEJMc1800098

11. Nielsen-Saines K, Brasil P, Kerin T, Vasconcelos Z, Gabaglia CR, Damasceno $\mathrm{L}$, et al. Delayed childhood neurodevelopment and neurosensory alterations in the second year of life in a prospective cohort of ZIKV-exposed children. Nat Med. (2019) 25:1213-7. doi: 10.1038/s41591-019-0496-1

12. Zin AA, Tsui I, Rossetto J, Vasconcelos Z, Adachi K, Valderramos $\mathrm{S}$, et al. Screening criteria for ophthalmic manifestations of congenital zika virus infection. JAMA Pediatr. (2017) 171:847. doi: 10.1001/jamapediatrics.2017.1474

13. Moher D, Liberati A, Tetzlaff J, Altman DG, The PRISMA Group. Preferred reporting items for systematic reviews and meta-analyses: the PRISMA statement. PLoS Med. (2009) 6:e1000097. doi: 10.1371/journal.pmed.1000097

14. Almeida IMLM de, Ramos CV, Rodrigues DC, Sousa AC de, Nascimento M de LCAPC do, Silva MVB da, et al. Aspectos clínicos e epidemiológicos da microcefalia no Estado do Piauí, Nordeste do Brasil, 2015-2016. J Pediatr. (2019) 95:466-74. doi: 10.1016/j.jped.2018.04.013

15. Alves LV, Paredes CE, Silva GC, Mello JG, Alves JG. Neurodevelopment of 24 children born in Brazil with congenital Zika syndrome in 2015: a case series study. BMJ Open. (2018) 8:e021304. doi: 10.1136/bmjopen-2017-021304

16. Aragao MFVV, Brainer-Lima AM, Holanda AC, van der Linden V, Vasco Aragão L, Silva Júnior MLM, et al. Spectrum of spinal cord, spinal root, and brain MRI abnormalities in congenital zika syndrome with and without arthrogryposis. AJNR Am J Neuroradiol. (2017) 38:10451053. doi: 10.3174/ajnr.A5125

17. Bertolli J, Attell JE, Rose C, Moore CA, Melo F, Staples JE, et al. Functional outcomes among a cohort of children in northeastern Brazil meeting criteria for follow-up of congenital Zika virus infection. Am J Trop Med Hyg. (2020) 102:955-63. doi: 10.4269/ajtmh.19-0961

18. Carvalho A, Brites C, Mochida G, Ventura P, Fernandes A, Lage ML, et al. Clinical and neurodevelopmental features in children with cerebral palsy and probable congenital Zika. Brain Dev. (2019) 41:587-94. doi: 10.1016/j.braindev.2019. 03.005
19. Carvalho MDCG, Miranda-Filho D de B, van der Linden V, Sobral PF, Ramos RCF, Rocha MÂW, et al. Sleep EEG patterns in infants with congenital Zika virus syndrome. Clin Neurophysiol. (2017) 128:20414. doi: 10.1016/j.clinph.2016.11.004

20. Carvalho-Sauer R, Costa M da CN, Barreto FR, Teixeira MG. Congenital Zika syndrome: prevalence of low birth weight and associated factors. Bahia, 2015-2017. Int J Infect Dis. (2019) 82:44-50. doi: 10.1016/j.ijid.2019.02.040

21. Contreras-Capetillo SN, Valadéz-González N, Manrique-Saide P, CarcañoCastillo RE, Pacheco-Tugores F, Barrera-Pérez HAM, et al. Birth defects associated with congenital zika virus infection in mexico. Clin Pediatr. (2018) 57:927-36. doi: 10.1177/0009922817738341

22. Costa Monteiro LM, Cruz GN de O, Fontes JM, de Araujo GF, Ventura T, Monteiro AC, et al. Neurogenic bladder in the settings of congenital Zika syndrome: a confirmed and unknown condition for urologists. J Pediatr Urol. (2019) 15:450.e1-450.e7. doi: 10.1016/j.jpurol.2019.06.021

23. Costa Monteiro LM, Cruz GN de O, Fontes JM, Saad Salles TRD, Boechat MCB, Monteiro AC, et al. Neurogenic bladder findings in patients with congenital Zika syndrome: a novel condition. PLoS ONE. (2018) 13:e0193514. doi: 10.1371/journal.pone.0193514

24. Cranston JS, Tiene SF, Nielsen-Saines K, Vasconcelos Z, Pone MV, Pone S, et al. Association between antenatal exposure to Zika virus and anatomical and neurodevelopmental abnormalities in children. JAMA Netw Open. (2020) 3:e209303. doi: 10.1001/jamanetworkopen.2020.9303

25. de Fatima Vasco Aragao $M$, van der Linden V, Brainer-Lima AM, Coeli RR, Rocha MA, Sobral da Silva P, et al. Clinical features and neuroimaging (CT and MRI) findings in presumed Zika virus related congenital infection and microcephaly: retrospective case series study. BMJ. (2016) 353:i1901. doi: 10.1136/bmj.i1901

26. de Paula Freitas B, de Oliveira Dias JR, Prazeres J, Sacramento GA, Ko AI, Maia M, et al. Ocular findings in infants with microcephaly associated with presumed Zika virus congenital infection in salvador, Brazil. JAMA Ophthalmol. (2016) 134:529. doi: 10.1001/jamaophthalmol.20 16.0267

27. de Paula Guimarães C, Macedo MS, Barbosa MA, Marques SM, Costa PS, de Oliveira ÊC. Clinical findings in congenital infection by Zika virus: a retrospective study in a reference hospital in central-west Brazil. BMC Pediatr. (2019) 19:389. doi: 10.1186/s12887-019-1762-6

28. dos Santos SFM, Soares FVM, de Abranches AD, da Costa ACC, GomesJúnior SC dos S, Fonseca V de M, et al. Nutritional profile of newborns with microcephaly and factors associated with worse outcomes. Clinics. (2019) 74:e798. doi: 10.6061/clinics/2019/e798

29. dos Santos SFM, Soares FVM, de Abranches AD, da Costa ACC, Moreira MEL, de Matos Fonseca V. Infants with microcephaly due to ZIKA virus exposure: nutritional status and food practices. Nutr J. (2019) 18:4. doi: 10.1186/s12937-019-0429-3

30. Fandiño-Cárdenas M, Idrovo AJ, Velandia R, Molina-Franky J, AlvaradoSocarras JL. Zika virus infection during pregnancy and sensorineural hearing loss among children at 3 and 24 months post-partum. J Trop Pediatr. (2019) 65:328-35. doi: 10.1093/tropej/fmy055

31. Felix A, Hallet E, Favre A, Kom-Tchameni R, Defo A, Fléchelles O, et al. Cerebral injuries associated with Zika virus in utero exposure in children without birth defects in french guiana: case report. Medicine. (2017) 96:e9178. doi: 10.1097/MD.0000000000009178

32. Ferreira H, Schiariti V, Regalado I, Sousa K, Pereira S, Fechine C, et al. Functioning and disability profile of children with microcephaly associated with congenital zika virus infection. IJERPH. (2018) 15:1107. doi: 10.3390/ijerph15061107

33. França T, Medeiros W, Souza N, Longo E, Pereira S, França T, et al. Growth and development of children with microcephaly associated with congenital Zika virus syndrome in Brazil. IJERPH. (2018) 15:1990. doi: 10.3390/ijerph15091990

34. Jucá E, Pessoa A, Ribeiro E, Menezes R, Kerbage S, Lopes T, et al. Hydrocephalus associated to congenital zika syndrome: does shunting improve clinical features? Childs Nerv Syst. (2018) 34:101-6. doi: 10.1007/s00381-017-3636-2

35. Kanda PAM, Aguiar A de AX, Miranda JL, Falcao AL, Andrade CS, Reis LN dos S, et al. Sleep EEG of microcephaly in Zika outbreak. Neurodiag J. (2018) 58:11-29. doi: 10.1080/21646821.2018.1428461 
36. C. Lage M-L, Carvalho A, Ventura P, Taguchi T, Fernandes A, Pinho S, et al. Clinical, neuroimaging, and neurophysiological findings in children with microcephaly related to congenital zika virus infection. IJERPH. (2019) 16:309. doi: 10.3390/ijerph16030309

37. Leal MC, Muniz LF, Ferreira TSA, Santos CM, Almeida LC, Van Der Linden $\mathrm{V}$, et al. Hearing loss in infants with microcephaly and evidence of congenital Zika virus infection - Brazil, November 2015-May 2016. MMWR Morb Mortal Wkly Rep. (2016) 65:917-9. doi: 10.15585/mmwr.mm6534e3

38. Leal MC, van der Linden V, Bezerra TP, de Valois L, Borges ACG, Antunes MMC, et al. Characteristics of dysphagia in infants with microcephaly caused by congenital Zika virus infection, Brazil, 2015. Emerg Infect Dis. (2017) 23:1253-9. doi: 10.3201/eid2308.170354

39. Leal M de C, Muniz LF, Caldas Neto S da S, van der Linden V, Ramos RCF, Leal $\mathrm{M}$ de $\mathrm{C}$, et al. Sensorineural hearing loss in a case of congenital Zika virus. Braz J Otorhinolaryngol. (2020) 86:513-5. doi: 10.1016/j.bjorl.2016.06.001

40. Leal MC, Seabra Ramos D, Pinto Bezerra T, Vilela AESC, Maciel RJ de F, Rodrigues $\mathrm{M}$, et al. The prevalence of adenoid hypertrophy among children with Zika related microcephaly. Viruses. (2021) 13:62. doi: 10.3390/v13010062

41. Leite RFP, Santos MSA, Ribeiro EM, Pessoa ALS, Lewis DR, Giacheti CM, et al. Triagem auditiva de crianças com síndrome congênita pelo vírus Zika atendidas em Fortaleza, Ceará, 2016. Epidemiol Serv Saúde. (2018) 27:e2017553. doi: 10.5123/S1679-49742018000400002

42. Linden V, Lins OG, Petribu NC, Melo ACMG, Moore J, Rasmussen SA, et al. Diaphragmatic paralysis: evaluation in infants with congenital Zika syndrome. Birth Defec Res. (2019) 111:1577-83. doi: 10.1002/bdr2.1597

43. Marques Abramov D, Saad T, Gomes-Junior S-C, de Souza e Silva D, Araújo I, Lopes Moreira ME, et al. Auditory brainstem function in microcephaly related to Zika virus infection. Neurology. (2018) 90:e60614. doi: 10.1212/WNL.0000000000004974

44. Melo A, Gama GL, Da Silva Júnior RA, De Assunção PL, Tavares JS, Da Silva $\mathrm{MB}$, et al. Motor function in children with congenital Zika syndrome. Dev Med Child Neurol. (2020) 62:221-6. doi: 10.1111/dmcn.14227

45. Meneses J do A, Ishigami AC, de Mello LM, de Albuquerque LL, de Brito CAA, Cordeiro MT, et al. Lessons learned at the epicenter of brazil's congenital zika epidemic: evidence from 87 confirmed cases. Clin Infect Dis. (2017) 64:1302-8. doi: 10.1093/cid/cix166

46. Moura da Silva AA, Ganz JSS, Sousa P da S, Doriqui MJR, Ribeiro MRC, Branco M dos RFC, et al. Early growth and neurologic outcomes of infants with probable congenital zika virus syndrome. Emerg Infect Dis. (2016) 22:1953-6. doi: 10.3201/eid2211.160956

47. Mulkey SB, Arroyave-Wessel M, Peyton C, Bulas DI, Fourzali Y, Jiang J, et al. Neurodevelopmental abnormalities in children with in utero Zika virus exposure without congenital Zika syndrome. JAMA Pediatr. (2020) 174:269. doi: 10.1001/jamapediatrics.2019.5204

48. Oliveira-Filho J, Felzemburgh R, Costa F, Nery N, Mattos A, Henriques DF, et al. Seizures as a complication of congenital zika syndrome in early infancy. Am J Trop Med Hyg. (2018) 98:1860-2. doi: 10.4269/ajtmh.17-1020

49. Orofino DHG, Passos SRL, de Oliveira RVC, Farias CVB, Leite M de FMP, Pone SM, et al. Cardiac findings in infants with in utero exposure to Zika virus- a cross sectional study. PLoS Negl Trop Dis. (2018) 12:e0006362. doi: 10.1371/journal.pntd.0006362

50. Ospina ML, Tong VT, Gonzalez M, Valencia D, Mercado M, Gilboa SM, et al. Zika virus disease and pregnancy outcomes in colombia. N Engl J Med. (2020) 383:537-45. doi: 10.1056/NEJMoa1911023

51. Pacheco O, Newton SM, Daza M, Cates JE, Reales JAM, Burkel VK, et al. Neurodevelopmental findings in children 20-30 months of age with postnatal Zika infection at 1-12 months of age, Colombia, September-November 2017. Paediatr Perinat Epidemiol. (2020) 35:92-7. doi: 10.1111/ppe.12690

52. Peçanha PM, Gomes Junior SC, Pone SM, Pone MV da S, Vasconcelos Z, Zin A, et al. Neurodevelopment of children exposed intra-uterus by Zika virus: a case series. PLoS ONE. (2020) 15:e0229434. doi: 10.1371/journal.pone.0229434

53. Petribu NC de L, Aragao M de FV, van der Linden V, Parizel P, Jungmann P, Araújo L, et al. Follow-up brain imaging of 37 children with congenital Zika syndrome: case series study. BMJ. (2017) 359:j4188. doi: 10.1136/bmj.j4188

54. Pinato L, Ribeiro EM, Leite RFP, Lopes TF, Pessoa ALS, Guissoni Campos LM, et al. Sleep findings in Brazilian children with congenital Zika syndrome. Sleep. (2018) 41:1-7. doi: 10.1093/sleep/zsy009
55. Pone MV da S. Contribuições Para o Conhecimento Sobre a Infecção Pelo Zika Vírus: a) Papel da USG Abdominal no Exame da Criança Exposta e b) Detecção Prolongada do Vírus em Adultos Não Grávidos. (2016). Available online at: https://sucupira.capes.gov.br/sucupira/public/consultas/coleta/ trabalhoConclusao/viewTrabalhoConclusao.jsf?popup=true\&id_trabalho= 4439383 (accessed October 14, 2020).

56. Pool K-L, Adachi K, Karnezis S, Salamon N, Romero T, Nielsen-Saines K, et al. Association between neonatal neuroimaging and clinical outcomes in zika-exposed infants from rio de Janeiro, Brazil. JAMA Netw Open. (2019) 2:e198124. doi: 10.1001/jamanetworkopen.2019.8124

57. Rajapakse NS, Ellsworth K, Liesman RM, Ho ML, Henry N, Theel ES, et al. Unilateral phrenic nerve palsy in infants with congenital Zika syndrome. Emerg Infect Dis. (2018) 24:1422-7. doi: 10.3201/eid2408180057

58. Rice ME, Galang RR, Roth NM, Ellington SR, Moore CA, Valencia-Prado $\mathrm{M}$, et al. Vital signs: Zika-associated birth defects and neurodevelopmental abnormalities possibly associated with congenital zika virus infection - U.S. Territories and freely associated states, 2018. MMWR Morb Mortal Wkly Rep. (2018) 67:858-67. doi: 10.15585/mmwr.mm6731e1

59. Rocha SGMO, Correia LL, da Cunha AJLA, Rocha HAL, Leite ÁJM, Campos JS, et al. Zika virus infection and microcephaly: a case-control study in Brazil. Ann Glob Health. (2019) 85:116. doi: 10.5334/aogh.2394

60. Roma JHF, Alves RC, Silva VS da, Ferreira MJ, Araújo C de, Pavoni JHC, et al. Descriptive study of suspected congenital Zika syndrome cases during the 2015-2016 epidemic in Brazil. Rev Soc Bras Med Trop. (2019) 52:e20190105. doi: 10.1590/0037-8682-0105-2019

61. Santana MB, Lamas CC, Athayde JG, Calvet G, Moreira J, De Lorenzo A. Congenital Zika syndrome: is the heart part of its spectrum? Clin Microbiol Infect. (2019) 25:1043-4. doi: 10.1016/j.cmi.2019.03.020

62. Satterfield-Nash A, Kotzky K, Allen J, Bertolli J, Moore CA, Pereira IO, et al. Health and development at age 19-24 months of 19 children who were born with microcephaly and laboratory evidence of congenital zika virus infection during the 2015 Zika virus outbreak - Brazil, 2017. MMWR Morb Mortal Wkly Rep. (2017) 66:1347-51. doi: 10.15585/mmwr.mm6649a2

63. Soares F, Abranches AD, Villela L, Lara S, Araújo D, Nehab S, et al Zika virus infection in pregnancy and infant growth, body composition in the first three months of life: a cohort study. Sci Rep. (2019) 9:19198. doi: 10.1038/s41598-019-55598-6

64. Soriano-Arandes A, Frick MA, García López-Hortelano M, Sulleiro E, Rodó C, Sánchez-Seco MP, et al. Clinical outcomes of a Zika virus mother-child pair cohort in Spain. Pathogens. (2020) 9:352. doi: 10.3390/pathogens 9050352

65. Subissi L, Dub T, Besnard M, Mariteragi-Helle T, Nhan T, Lutringer-Magnin $\mathrm{D}$, et al. Zika virus infection during pregnancy and effects on early childhood development, french polynesia, 2013-2016. Emerg Infect Dis. (2018) 24:18508. doi: $10.3201 /$ eid2410.172079

66. Sulleiro E, Frick MA, Rodó C, Espasa M, Thorne C, Espiau M, et al. The challenge of the laboratory diagnosis in a confirmed congenital Zika virus syndrome in utero: a case report. Medicine. (2019) 98:e15532. doi: 10.1097/MD.0000000000015532

67. Trigueiro SA, Neves BF, Aguiar de MSB, Araújo de JSS. Correlation between cephalic circumference at birth and ocular alterations in patients with microcephaly potentially associated with Zika Virus infection. Rev Assoc Med Bras. (2019) 65:909-13. doi: 10.1590/1806-9282.65. 6.909

68. Tsui I, Moreira MEL, Rossetto JD, Vasconcelos Z, Gaw SL, Neves LM, et al. Eye findings in infants with suspected or confirmed antenatal zika virus exposure. Pediatrics. (2018) 142:e20181104. doi: 10.1542/peds.2018-1104

69. van der Linden H, Silveira-Moriyama L, van der Linden V, Pessoa A, Valente $\mathrm{K}$, Mink J, et al. Movement disorders in children with congenital Zika virus syndrome. Brain Dev. (2020) 42:720-9. doi: 10.1016/j.braindev.2020. 06.016

70. van der Linden V, Filho ELR, Lins OG, van der Linden A, Aragão M de FVV, Brainer-Lima AM, et al. Congenital Zika syndrome with arthrogryposis: retrospective case series study. BMJ. (2016) 354:i3899. doi: 10.1136/bmj.i3899

71. van der Linden V, Pessoa A, Dobyns W, Barkovich AJ, Júnior $H$ van der L, Filho ELR, et al. Description of 13 infants born during October 2015January 2016 with congenital Zika virus infection without microcephaly at birth - Brazil. MMWR Morb Mortal Wkly Rep. (2016) 65:13438. doi: 10.15585/mmwr.mm6547e2 
72. de Vasconcelos RAL, Ximenes RAA, Calado AA, Martelli CMT, Gonçalves AV, Brickley EB, et al. Cryptorchidism in children with Zika-related microcephaly. Am J Trop Med Hyg. (2020) 102:982-4. doi: 10.4269/ajtmh.19-0753

73. Ventura CV, Maia M, Travassos SB, Martins TT, Patriota F, Nunes ME, et al. Risk factors associated with the ophthalmoscopic findings identified in infants with presumed Zika virus congenital infection. JAMA Ophthalmol. (2016) 134:912. doi: 10.1001/jamaophthalmol.2016.1784

74. Ventura LO, Ventura CV, Dias N de C, Vilar IG, Gois AL, Arantes TE, et al. Visual impairment evaluation in 119 children with congenital Zika syndrome. J Am Assoc Pediatric Ophthalmol Strab. (2018) 22:21822.e1. doi: 10.1016/j.jaapos.2018.01.009

75. Veras Gonçalves A, Miranda-Filho D de B, Rocha Vilela LC, Ramos RCF, de Araújo TVB, de Vasconcelos RAL, et al. Endocrine dysfunction in children with zika-related microcephaly who were born during the 2015 epidemic in the state of pernambuco, Brazil. Viruses. (2020) 13:1. doi: 10.3390/v13010001

76. Verçosa I, Carneiro P, Verçosa R, Girão R, Ribeiro EM, Pessoa A, et al. The visual system in infants with microcephaly related to presumed congenital Zika syndrome. J Am Assoc Pediatr Ophthalmol Strab. (2017) 21:3004.e1. doi: 10.1016/j.jaapos.2017.05.024

77. Walker CL, Ehinger N, Mason B, Oler E, Little M-TE, Ohuma EO, et al. Ultrasound prediction of Zika virus-associated congenital injury using the profile of fetal growth. PLoS ONE. (2020) 15:e0233023. doi: 10.1371/journal.pone.0233023

78. Zin AA, Tsui I, Rossetto JD, Gaw SL, Neves LM, Zin OA, et al. Visual function in infants with antenatal Zika virus exposure. J Am Assoc Pediatr Ophthalmol Strab. (2018) 22:452-6.e1. doi: 10.1016/j.jaapos.2018.07.352

79. Ventura LO, Ventura CV, Lawrence L, van der Linden V, van der Linden A, Gois AL, et al. Visual impairment in children with congenital Zika syndrome. J Am Assoc Pediatr Ophthalmol Strab. (2017) 21:2959.e2. doi: 10.1016/j.jaapos.2017.04.003

80. Paul AM, Acharya D, Neupane B, Thompson EA, Gonzalez-Fernandez G, Copeland KM, et al. Congenital Zika virus infection in immunocompetent mice causes postnatal growth impediment and neurobehavioral deficits. Front Microbiol. (2018) 9:2028. doi: 10.3389/fmicb.2018.02028

81. Wu Y-H, Cui X-Y, Yang W, Fan D-Y, Liu D, Wang P-G, et al. Zika virus infection in hypothalamus causes hormone deficiencies and leads to irreversible growth delay and memory impairment in mice. Cell Rep. (2018) 25:1537-47.e4. doi: 10.1016/j.celrep.2018. 10.025
82. Saad T, PennaeCosta AA, de Góes FV, de Freitas M, de Almeida JV, de Santa Ignêz LJ, et al. Neurological manifestations of congenital Zika virus infection. Childs Nerv Syst. (2018) 34:73-8. doi: 10.1007/s00381-0173634-4

83. Cohen BE, Durstenfeld A, Roehm PC. Viral causes of hearing loss: a review for hearing health professionals. Trends Hearing. (2014) 18:2331216514541361. doi: 10.1177/2331216514541361

84. Kapogiannis BG, Chakhtoura N, Hazra R, Spong CY. Bridging knowledge gaps to understand how zika virus exposure and infection affect child development. JAMA Pediatr. (2017) 171:478. doi: 10.1001/jamapediatrics.2017.0002

85. Adams Waldorf KM, McAdams RM. Influence of infection during pregnancy on fetal development. Reproduction. (2013) 146:R151-62. doi: 10.1530/REP-13-0232

86. Martinot AJ, Abbink P, Afacan O, Prohl AK, Bronson R, Hecht JL, et al. Fetal neuropathology in Zika virus-infected pregnant female rhesus monkeys. Cell. (2018) 173:1111-22.e10. doi: 10.1016/j.cell.2018.03.019

Conflict of Interest: The authors declare that the research was conducted in the absence of any commercial or financial relationships that could be construed as a potential conflict of interest.

The handling editor declared to have joint publications with the authors $\mathrm{PB}$, KN-S, and MM.

Publisher's Note: All claims expressed in this article are solely those of the authors and do not necessarily represent those of their affiliated organizations, or those of the publisher, the editors and the reviewers. Any product that may be evaluated in this article, or claim that may be made by its manufacturer, is not guaranteed or endorsed by the publisher.

Copyright (C) 2021 Amaral, Malacarne, Brandão, Brasil, Nielsen-Saines and Moreira. This is an open-access article distributed under the terms of the Creative Commons Attribution License (CC BY). The use, distribution or reproduction in other forums is permitted, provided the original author(s) and the copyright owner(s) are credited and that the original publication in this journal is cited, in accordance with accepted academic practice. No use, distribution or reproduction is permitted which does not comply with these terms. 